\title{
Analysis of the Variables that Affect Bookstore Customer Satisfaction
}

\author{
Elis Ratna Wulan ${ }^{1^{*}}$ \\ Uus Ahmad Husaeni² \\ ${ }^{1}$ Mathematics Department, Science and Technology Faculty, \\ Islamic State University Bandung, Indonesia. \\ 2Sharia Economics Department, Postgraduate Program, \\ Islamic State University Bandung, Indonesia. \\ *Corresponding Author, Email: elis_ratna_wulan@uinsgd.ac.id
}

\begin{abstract}
:
Competition, which becomes more widespread, complex, and intense, drives companies to must be able to see the various opportunities that exist and to identify strategies for creating customer satisfaction. As an example of a company must be able to produce products with good quality, reasonable price, facilities, and companies are able to create a positive image in the eyes of consumers. This strategy is quite important in facing the competitive level of competition with rival firms. This research is aimed to analysis simultaneously or partially positive effect of the facilities, prices and corporate image on customer satisfaction, as well as analyzing the most dominant variable in effecting bookstore customer satisfaction. Data used in this research are primary data from Tmbookstore customer in Cianjur city, West Java Indonesia, which were collected from respondents using valid and reliable questionnaire. A total of 100 respondents were selected from Tmbookstore visitors by accidental sampling. Data were analyzed using multiple regression analysis. Results of the research indicate that product, price, location, and simultaneously affect to bookstore consumer satisfaction. Partially, only two of the three variables that affect bookstore consumer satisfaction namely price and company image. Image of the company is the most a dominant impact on bookstore customer satisfaction.
\end{abstract}

Keywords: Facilities, Price, Image of corporate, Customer satisfaction

\section{A. INTRODUCTION}

The more extensive, complex and rapid faced competition, causing many companies are looking for profitable ways to differentiate themselves from the others. (Hadiati and Ruci, 1999). Companies are required to be able to see the various opportunities that exist and seek strategies or ways to deliver consumer or customer satisfaction and maintain, for example, the company should be able to provide products with good quality, reasonable price, complete facilities, and is capable of creating a positive image of the company in the eyes of consumers. If a consumer in person has been transformed into a loyal customer because satisfaction is not met then the consumer will switch to the products / services of other similar companies (Hapsari, 2004).

Tmbookstore is a company engaged in the sale of books and stationery are also trying to provide the best products and services to be given to consumers. For example, in order to provide 
satisfaction for its customers, then Tmbookstore always trying to present a calm and comfortable atmosphere. In addition, completeness of the facility was constantly improved so that consumers are increasingly satisfied and are keen to come again and repeatedly make a purchase because of their direct gifts or discount prices every day.

The purpose of this study is to analyze the positive influence of the facilities, prices and corporate image simultaneously and partially on consumer satisfaction, as well as analyze the most dominant variable in influencing customer satisfaction.

\section{B. METHODS}

The research use customer satisfaction concept to analyze the phenomena by using questionnaires sent to respondents. The data used in this study are primary data in the form of results of a questionnaire distributed to the visitors Tmbookstore. Distributing questionnaires conducted on Wednesday, June 12, 2013 and ending on Thursday, July 13, 2013. The variables studied by the author can be divided into two. The first variable is called independent variables consisting of variable facilities, price and company image. While the second variable is called the dependent variable is the level of customer satisfaction Tmbookstore.

Population and sample of this research is all visitors Tmbookstore. The number of respondents who specified by 100 respondents. The samples using nonprobability sampling, in particular by accidental sampling, which means sampling by coincidence, that anyone who by chance met and elected will be the respondent.

\section{Consumer Behavior}

According to Simamora (2002), consumer behavior is an action that is directly involved to get, consume, and spent products and services, including the decision processes that precede and follow this action. While according to Kotler (2005), consumer behavior is an orderly process by which individuals are integrated with the environment for the purpose of making decisions in the market of goods or services (Kotler, 2005).

From some of the above understanding can be said that consumer behavior is a process that is carried out by consumer behavior in planning a purchase that is made up of several stages, namely, search, buy, use, and evaluate whether the goods or services that have been purchased is to give satisfaction or meet the needs of a consumers.

\section{Services}

Definition of services according to Rangkuti (2002) is giving a measure of performance or invisible from one party to another. In general services are consumed and produced simultaneously, where the interaction between service providers and service recipients influence the outcome of such services. While according to Kotler (2005), which defines services as any action or activity that can be offered by one party to another, which is essentially intangible and does not result in any ownership. Production can be associated or not associated with a physical product.

\section{Quality Services}

In providing quality services as an attempt to achieve customer satisfaction, the company can be based on the dimensions of service quality. According to Kotler (1994), there are five determinants 
of quality of services. Fifth determinants include reliability, which is defined as the ability to perform the promised services accurately and reliably. The next determinant is responsive, is the responsiveness is the wish of the company to help customers and provide fast and responsive services. After responsiveness determinants that must be met is the belief, in this case the knowledge and courtesy of employees and their ability to generate trust and confidence. The next determinant of service quality is empathy and tangible, empathy question is suppose to care and give personal attention to consumers, while the tangible means the appearance of physical facilities, equipment, employees and media communications.

The quality of services offered can be assessed through two viewpoints. The first viewpoint is judged by the quality of the technique by which the quality of services can be determined from the work of service delivery itself. The second viewpoint is through quality service process which includes the delivery of services. In other words, there are two main factors that affect the quality of services, i.e. services that are expected and the services received. If the services received or perceived in line with expectations, the perceived service quality is good and satisfying and if the services received exceed the expectations of customers, the quality of service perceived as the ideal of service quality (Schifffman and Kanuk, 2004).

\section{Price}

Consumers view specific price either high, low or reasonable to have a strong influence on the purpose of purchasing and satisfaction. For example, in terms of the perception of the fairness of the price at which the consumer generally pays attention to the prices paid by other consumers.

Schiffman and Kanuk (Schiffman and Kanuk, 2004) says there is the impact of price perception consumers caused by three types of reference prices, among others, low and reasonable prices, high and reasonable proces, the last high and unreasonable prices. Low and reasonable prices is within the range of acceptable market price, high and reasonable prices located near the outer limits of the price range but can not pass through field that can be trusted. Whereas high and unreasonable price is far above the limits of the range of market prices acceptable to consumers. It indicates that the consumer would prefer a type of low and reasonable prices before buying a product or services (Schiffman and Kanuk, 2004).

Lupiyoadi and Hamdani (2006) says that if a product or service requires customers to pay greater than manfaatyang acceptable, then what happens is that these goods and services have a negative value. Consumers might think of it as a poor value and then will reduce consumption because it was not satisfied.

\section{Factors that affect the pricing of services}

The factors to be considered in determining the price of such services is the elasticity of demand, the services help managers understand the relationship between price and demand and demand variations at different levels of pricing. The second factor is the cost structure, helps managers understand the cost of the provision of services and the services of these cost variations over time and based on the level of demand. Then the third factor is competition, understanding of the cost of competitors' services can help managers conduct an assessment of the capacity of competitors to change the pricing structure. Fourth, the positioning of the services offered. Fifth, the target to be achieved by the company. The sixth factor, lifecycle services, including the desired level of profitability to ensure survival. Seventh, the resources used and the final factor is the economy (Adhinugroho, 2002). 


\section{Image}

Image is the radiance or reproduction of identity or form individuals, objects or organization (Amirullah, 2002). For the company's image can also be interpreted as the public perception of corporate identity. One's perception of the company based on what they know or they think about the company concerned.

The image of the company became one of the handles for many people in taking a wide range of important decisions. Examples of such decisions are buying goods or services produced by the company (the consumer), subscription (customers) and recommend the company's products to others. Another example is the decision to give credit (bank creditors), providing credit sales of goods or services (company suppliers), buy stocks or bonds issued by the company (investor) and give a business license or concession (government agencies).

Good corporate image is a competitive advantage that affect customer satisfaction. Therefore, companies must periodically survey consumers to find images that are embedded in mind of each consumer (Marlien and Suprapto, 2005). According Hawkin et al. (2000), the process to form the image of the company took place in several stages. First, the object of knowing (seeing or hearing) the efforts of the company in forming the image of the company. Second, the effort shows. Third, once the object of attention trying to understand all that exists in the company's efforts. Fourth, the establishment of corporate image on the object and then the fifth stage of the company's image that is formed will determine the behavior of the target object, in other words consumers, in conjunction with the company.

\section{Customer Satisfaction}

Satisfaction according to Kotler and Keller (2006) is feeling happy or upset someone who comes after a comparison between the perception or impression of the performance (or result) of a product and hopes. Consumer satisfaction is a very important part in the framework of the success of a business. Many firms say that the main purpose of the company is to satisfy consumer. Many kinds of disclosure, because that satisfaction is something abstract and difficult to measure. Everyone has its own assessment of the satisfaction desired, then the success of a company is determined by the satisfaction that can be given to consumers (Kusumawati, 2007).

According Kottler (2002), the company that is able to deal with complaints of consumers effectively is a company that develops training programs and employee acceptance criteria taking into account the role of improved service employees, develop guidelines for improvement of services that focus on achieving adequate treatment and customer satisfaction, dismantle all barriers that complicate the customer to make a complaint, while developing effective response, which may include compensation for the failure to provide services and maintain a data base of products and customers enables companies to analyze the type and source of complaints as well as adjust its policies.

Data analysis techniques used in this study is as follows:

\section{a. Likert Scale}

RS Likert (1932) developed a scaling procedure in which the scale represents a bipolar countinum. At the left end with lower numbers describe a negative answer while the right end with large numbers 
illustrate a positive answer. Likert-type format is designed to allow customers responded in varying degrees on each item that describes services or products. Goodness use Likert-type format in comparison with the check list format that only give an answer "yes" or "no", is that the type Likert reflect the diversity of value as a result of the use of scales in the study ranged from 1 to 5 . With dimensions of quality that is reflected in the list questions, allowing respondents to express their opinion in the level of services received closer to the truth (Santoso, 2006).

\section{b. Validity Analysis}

Validity indicates the level or degree of being used as evidence to support the conclusions drawn from the value derived from the size or scale to measure the degree to which something is supposed to be measured. The data is said to be valid when the value Correced Item greater than the value of $r$ table with $\mathrm{df}=\mathrm{n}-2$.

\section{c. Reliability Analysis}

Reliability is defined as the extent of the variance error-free measurement. In estimating the reliability of the variables studied researcher using Cronbach's Alpha (Cronbach, 1951). Alpha Cronbach's approximate calculation is usually done with SPSS software which is designed to be able to calculate the estimate of reliability. A variable is said to be reliable if the value of Cronbach's Alpha > 0.6.

\section{d. Correlation Analysis}

Correlation analysis is part of the testing associative aiming for strength, significance, and direction of the relationship between the two variables. Direction of the relationship that will tested the correlation analysis can be categorized according to three patterns towards relationships. The first pattern is a positive relationship or relationship unidirectional pattern. The second pattern is a negative correlation or relationship patterned opposite direction, and the last is a pattern where no pattern direction of the relationship. In measuring the degree of correlation, the authors using Pearson correlation method through computerized with SPSS software.

\section{e. Regression Analysis}

Regression analysis is a type of parametric analysis can provide a basis for predicting and analyzing the variants (Sugiyono, 2008). Some of the objectives of doing the regression analysis, among others, to determine the regression line equation based on the value of the constants and the resulting regression coefficients, looking for correlations together between independent variables with the dependent variable, and testing the significance of independent variables on the dependent variable through $F$. To test for correlations partially between independent variables with the dependent variable, and examine the significance of independent variables on the dependent variable through the t test (Sudarmanto, 2005).

\section{RESULT AND DISCUSSIONS}

\section{Validity and Reliability Test}

Validity and reliability test conducted to determine how many questions are valid and reliable by conducting a survey of 100 respondents. The calculation result validity and reliability of questionnaire items in Table 1. 
Table 1. Operationalization Facility, Price, Corporate Image, and Customer Satisfaction Variables

\begin{tabular}{|c|c|c|c|}
\hline Variable & Item & Correlated Items & Cronbach's Alpha \\
\hline \multirow{10}{*}{ Facility } & $\mathrm{F} 1$ & 0.340 & \multirow{10}{*}{0.814} \\
\hline & $\mathrm{F} 2$ & 0.514 & \\
\hline & F3 & 0.511 & \\
\hline & F4 & 0.472 & \\
\hline & F5 & 0.333 & \\
\hline & F6 & 0.454 & \\
\hline & F7 & 0.669 & \\
\hline & F8 & 0.530 & \\
\hline & F9 & 0.597 & \\
\hline & F10 & 0.512 & \\
\hline \multirow{10}{*}{ Price } & $\mathrm{H} 12$ & 0.765 & \multirow{10}{*}{0.906} \\
\hline & $\mathrm{H} 13$ & 0.754 & \\
\hline & $\mathrm{H} 14$ & 0.724 & \\
\hline & $\mathrm{H} 15$ & 0.534 & \\
\hline & $\mathrm{H} 16$ & 0.595 & \\
\hline & $\mathrm{H} 17$ & 0.709 & \\
\hline & $\mathrm{H} 18$ & 0.741 & \\
\hline & $\mathrm{H} 19$ & 0.675 & \\
\hline & $\mathrm{H} 2 \mathrm{O}$ & 0.476 & \\
\hline & $\mathrm{H} 21$ & 0.724 & \\
\hline \multirow{11}{*}{ Corporate Image } & $\mathrm{C} 22$ & 0.382 & \multirow{11}{*}{0.843} \\
\hline & $\mathrm{C} 23$ & 0.526 & \\
\hline & $\mathrm{C} 24$ & 0.595 & \\
\hline & $\mathrm{C} 25$ & 0.574 & \\
\hline & $\mathrm{C} 26$ & 0.635 & \\
\hline & $\mathrm{C} 27$ & 0.437 & \\
\hline & $\mathrm{C} 28$ & 0.461 & \\
\hline & $\mathrm{C} 29$ & 0.580 & \\
\hline & $\mathrm{C} 30$ & 0.552 & \\
\hline & C31 & 0.623 & \\
\hline & $\mathrm{C} 32$ & 0.467 & \\
\hline \multirow{13}{*}{ Costumer Satisfaction } & KK33 & 0.655 & \multirow{13}{*}{0.914} \\
\hline & KK34 & 0.614 & \\
\hline & KK35 & 0.611 & \\
\hline & KK36 & 0.561 & \\
\hline & KK37 & 0.610 & \\
\hline & KK38 & 0.558 & \\
\hline & KK39 & 0.694 & \\
\hline & KK40 & 0.589 & \\
\hline & KK41 & 0.665 & \\
\hline & KK42 & 0.730 & \\
\hline & KK43 & 0.675 & \\
\hline & KK44 & 0.677 & \\
\hline & KK45 & 0.727 & \\
\hline
\end{tabular}

Based on Table 1, it is known that all items remaining questions on each variable declared valid because it is positive $(+)$ and the value is greater than 0.194 ( $r$ table) with $\mathrm{df}=\mathrm{n}-2$ or $\mathrm{df}=43$. Cronbach's Alpha value of each variable larger of 0.6 , which ranged from 0.814 to 0.914 , so that the four variables are declared reliable. 


\section{Correlation Analysis}

Results of correlation analysis facilities, prices, and corporate image on customer satisfaction variables using the Pearson correlation coefficient, knowable the relationship between the variables is as follows:

\section{a. The relationship between the facility and corporate image}

A large relationship between facility and corporate image is 0.461 showing strong enough correlation between the variables of the facility and coporate image. Sign (+) indicates that facility and the corporate image have unidirectional relationship, meaning that the higher the value of facility, the higher the value of corporate image.

\section{b. The relationship between facility and customer satisfaction}

A large relationship between facility and customer satisfaction is 0.307 showing strong enough correlation between facility and customer satisfaction variables. Sign (+) indicates that facilities and consumer satisfaction have unidirectional relationship, meaning that the higher the value of the facility, the higher the value of customer satisfaction.

\section{c. The relationship between the price and the corporate image}

A large relationship between price and the corporate image is 0.209 showing strong enough correlation between the price and the corporate image variables. Sign $(+)$ indicates that the price and the corporate image have unidirectional relationship, meaning that the higher the value of the price, the higher the value of the corporate image.

\section{d. The relationship between price and customer satisfaction}

A large relationship between price and customer satisfaction is 0.292 showing strong enough correlation between the price and customer satisfaction variables. Sign (+) indicates that price and customer satisfaction have unidirectional relationship, meaning that the higher the value of the price, the higher the value of the customer satisfaction.

\section{e. The relationship between the corporate image and customer satisfaction}

A large relationship between the corporate image and customer satisfaction is 0.393 showing strong enough correlation between the corporate image and customers satisfaction variables. Sign $(+)$ indicates that the corporate image and customer satisfaction have unidirectional relationship, meaning that the higher the value of the corporate image, the higher the value of customer satisfaction.

\section{Regression Analysis}

After going through the correlation analysis stages of all three independent variables on the dependent variable, the next stage is performing a regression analysis to determine the influence of independent variables on the dependent variable. The results of the regression analysis is in the form of regression equation as follows:

$$
y=0,651+0,188 x_{1}+0,260 x_{2}+0,318 x_{3}
$$


Based on consumer satisfaction research model using regression methods and results of calculations known coefficient Beta Standards of variable facilities directly affects consumer satisfaction is equal to $17.56 \%$, while for the variables directly affect the prices of consumer satisfaction by $35.81 \%$, and for variable image of the company can directly affect customer satisfaction by $46.62 \%$.

\section{CONCLUSION}

Based on the results of the study that has been discussed, it can be concluded that, facility, price, and corporate image affecting simultaneously on bookstore customer satisfaction. Facility variable represented by layout service providers always gives a good impression for customers, price variable represented by the price given in accordance with quality products offered and corporate image variable is represented by responsive employees, friendly and courteous. These three variables have a significant influence on consumer satisfaction.

Partially price and corporate image variable has positive and significant affect to customer satisfaction. Instead, facility variable in this model have no positive and significant affect on customer satisfaction.

The corporate image is represented by the employee responsive, friendly and courteous. The corporate image has the most affect on bookstore customer satisfaction.

Based on the conclusion, the bookstore should prioritize improvements on variables that are still considered less by the customer. Bookstore should be able to use the results of this study and always monitor the ever-changing customer needs in a rapidly changing environment, so the bookstore is able to anticipate and meet customer needs. With the fulfillment of customer needs, it can be built customer satisfaction because customer satisfaction is at the core of achieving the longterm profitability. 


\section{References}

Adhinugroho, H. (2002). Sistem Informasi Pemasaran dan Environmental Scanning Pengaruhnya terhadap Kualitas Layanan, Keunggulan Bersaing dan Pertumbuhan Pelanggan. Jurnal Sains Pemasaran Indonesia. 1 (1), pp. 275 - 291.

Amirullah. (2002). Perilaku Konsumen. Yogyakarta: Graha Ilmu.

Hadiati, S. And Ruci, S. (1999). Analisis Kinerja Kualitas terhadap Kepuasan Pelanggan pada Telkomsel Malang Area. Jurnal Manajemen dan Kewirausahaan. 1 (1), pp. 56 - 64.

Hapsari, K.R. (2004). Analisis Kepuasan Konsumen terhadap Layanan Jasa Hotel Salak Bogor. Thesis. IPB. Unpublished.

Kotler, P. (2005). Manajemen Pemasaran. Jakarta: PT. Indeks Kelompok Gramedia.

Schiffman, L.G, and L. L Kanuk. (2004). Perilaku Konsumen Seventh Edition. Jakarta: PT. Indeks Kelompok Gramedia.

Kusumawati, R. (2007). Analisis Pengaruh Image, Kualitas yang Dipersepsikan, Harapan pada Kepuasan Nasabah dan Pengaruh Kepuasan Nasabah pada Loyalitas Nasabah dan Perilaku Beralih Merek. Jurnal Ekonomi dan Bisnis. 1 (1), pp. 53 - 62.

Marlien and Suprapto, P. (2005). Faktor-Faktor Pembentuk Persepsi Kualitas Layanan terhadap Reputasi, Kepuasan, serta Loyalitas PT. Asuransi Jiwasraya (Persero) Semarang Timur Branch Office. Jurnal Bisnis dan Ekonomi. 12 (2), pp. 225 - 247.

Santoso, S. (2006). Menggunakan SPSS untuk Statistik Multivariat. Jakarta: Elex Media Komputindo.

Schiffman, L.G. and Kanuk, L. L. (2004). Perilaku Konsumen Seventh Edition. Jakarta: PT. Indeks Kelompok Gramedia.

Sudarmanto, R.G. (2005). Analisis Regresi Linier Ganda dengan SPSS. Yogyakarta: Graha Ilmu.

Sugiyono. (2008). Metode Penelitian Bisnis (Pendekatan Kuantitatif, Kualitatif, dan $R$ \& D). Bandung: Alfabeta. 
